\title{
IMPACT OF SOCIO-ECONOMIC FACTORS IN REDUCING MALNUTRITION AMONG CHILDREN: A COMPARATIVE STUDY OF INDIA, BANGLADESH AND SRI LANKA
}

\author{
Prema Basargekar, Sushmita Priyadarshini, Shubham Seth, Vaibhav Ganjoo \\ K J Somaiya Institute of Management, Mumbai, India
}

Correspondence:prema@somaiya.edu

\begin{abstract}
OBJECTIVE

To assess the impact of economic and gender factors on malnutrition among children below 5 years of age by making a comparative study between India, Bangladesh and Sri Lanka
\end{abstract}

\section{DESIGN AND SETIING}

The study uses data and information on economic and gender status parameters taken from the secondary sources for three South Asian Countries between the years 2000 to 2018. The study uses ANOVA, Post Hoc test and Fixed Effects Panel Regression analysis to arrive at the conclusions.

\section{RESULTS}

Comparative analysis between the three countries shows that the extent of malnutrition among children is lowest in Sri Lanka and highest in India. The study finds that economic factors such as domestic government's expenditure of healthcare as percentage of total health expenditure and gender factors measured in terms of female labour force participation, and school enrolment of girls at secondary level significantly impact the level of malnutrition among children.

\section{CONCLUSION}

Malnutrition among children is a complex challenge which cannot be solved by emphasizing on only economic growth. Policies em phasising on gender parity and empowerment integrated in healthcare policies will positively impact nutritional level of children.

\section{KEYWORDS}

Malnutrition, Children, Socio-economic factors, Gender policies, South Asian countries 
Malnutrition among children is a consequence of socioeconomic and gender construct such as lack of access to nutritious food, basic healthcare facilities, status of maternal health as well as maternal awareness related to the causes and implications of malnutrition in children. Malnutrition among children has higher socio-economic consequences such as high child mortality, high level of morbidity due to higher susceptibility to infections and illness which further leads to lower level of human capital and productivity implying lower economic growth. India is infamous for a very high prevalence of malnutrition among children up to 5 years old. According to National Family Health Survey IV for the year 2014-15, as many as 69.4 per cent of children below five years are anaemic. India lags behind many other developing countries which are closer and similar in socio-economic conditions such as Sri Lanka and Bangladesh. COVID 19 has worsened the situation due to reduced access of basic healthcare and nutritious food to the children. Few of the government programs such as Integrated Child Development Services (ICDS) could not get implemented at the grassroots level effectively due to overburden on overall health system and restrictions on mobility of health workers.

The World Health Organization (WHO) defines malnutrition as deficiencies, excesses, or imbalances in a person's intake of energy and/or nutrients. It can take various forms such as under nutrition (such as wasting, stunting, underweight, and deficiencies in vitamins and minerals), Micronutrient- related malnutrition (inadequate intake of vitamins and minerals), overweight and obesity and dietrelated non-communicable diseases. The extent of malnutrition among children is very high across the globe. WHO has estimated that globally nearly 144 million children under the age of 5 years were stunted, 47 million were wasted and 38 million were overweight in 2019. It is one of the major causes of illness and death among children in developing economies. [1] Children are also be affected by micronutrient deficiencies, which also have an adverse effect on their growth and development. The most common and clinically significant micronutrient deficiencies in children and childbearing women throughout the worldinclude deficiencies of iron, iodine,

1 http://rchiips.org/nfhs/pdf/NFHS4/India.pdf

2 https://www. who.int/news-room/fact-sheets/detail/malnutrition 3 https://www. who.int/nutgrowthdb/jme-2019-key-findings.pdf

4 https://globalnutritionreport.org/reports/global-nutrition-report-2018/

5. Published Online July 27, 2020 https://doi.org/10. 1016/ S0140-

$6736(20) 31647-$ zinc, and vitamin A to name a few. They are estimated to affect as many as two billion people. It is seen that the impact of malnutrition usually falls mainly on the health status of children under five years of age. [2]

COVID-19 is likely to have a very high negative impact on nutritional level of children. [3] It has brought out various risk factors such as food insecurity and poor quality diet, reduced incomes and lack of access to financia resources, limited health services and interrupted education. These all are likely to lead higher level of malnutrition among children during and post COVID-19 period. As per the estimate of one of the study made by Lancet, the extent of malnutrition among children in low income countries is likely to increase by $14.3 \%$ due to fall in per capita income during the pandemic.

The research shows that children malnutrition is highly related to the gender status in terms of women's access to healthcare, higher education and economic opportunities. National Family Health Survey, India report published in 2018 clearly mentions that children whose mothers have less education have lower nutritional levels than that of better educated mothers. [4] One study from Bangladesh also showed that prevalence of malnutrition among children has significantly reduced with higher level of maternal education. [5]. Women's education along with other precautionary measures such as vaccination, prompt treatment for diarrhoea and sanitation facilities have a positive impact on reducing malnutrition among children. [6] One study on maternal health services of 31 developing countries proves a positive linkage between economic and educational empowerment of women and use of maternal healthcare services. [7] Researchers suggest that gender disparities also need to be addressed at the early age by promoting girl's education and implementing nutrition sensitive interventions for them. [3,8]

The research till date shows a positive relationship between economic development and public health expenditure and children's health status. Economic inequity and lower economic growth leads to undernourishment of children. [9] Public health expenditure can reduce up to 4.4 child mortality in every 1000 live births and can enhance the lifeexpectancy at birth by 47 days in a year. [10] An increase of $10 \%$ in public expenditure of social sector along with public health helps in reduction in mortality rates and morbidity rates among children. [1 1 ] 
The research shows the effectiveness of policyinterventions at the country level on the nutritional level of children. One of the success factors of reduction in malnutrition among children in Bangladesh is the effective policyintervention in empowering women. [8] The evaluation study made by the World Bank in 2005 gives credit to well executed policy of providing key resources and personnel for executing 'The Bangladesh Integrated Nutrition Project', making vitamin A and iron supplements easily available and promoting better infant feeding practices. [12] Sri Lanka made a significant progress in the field of child health and nutrition by implementing sound health policies improving its public health care system and thereby reducing the disease burden. [13]

India lags behind Sri Lanka and Bangladesh in meeting the targets of reduction in malnutrition. Main reasons are found in its inadequate health infrastructure and healthcare personnel as well as inaccessibility and low level of utilization of health services. [14] One of the ICDS evaluation study shows that the efficacy of the programme is limited due to high level of inequality between urban and rural areas and between different regions which resulted into low services utilization and lack of continuum of care services from pregnant women to breast feeding practices till the child becomes 6 years old. [15]

The literature gap exists in terms of specifying succinctly how these economic and gender status factors impact the malnutrition status especially in developing economics like India. The present study attempts to fill this gap by making a comparative study of three South Asian countries - India, Sri Lanka and Bangladesh which are similar in socioeconomic and cultural context but are significantly different in achieving the target of reducing malnutrition among children.

\section{OBJECTIVES}

The purpose of the study is to make a comparative analysis between India, Bangladesh and Sri Lanka to assess their progress in reducing the level of malnutrition among children and to assess the impact of socio-economic factors affecting the extent of malnutrition among children. The specific objectives are

- To make a comparative analysis of the status and the trends in reducing malnutrition among children in India, Sri Lanka and Bangladesh
- To assess the impact of economic and gender factors on the level of malnutrition among children

\section{METHODOLOGY ADOPTED}

The study uses secondary data pertaining to the period between the years 2000 and 2018. It uses following economic and gender indicators:

1. Prevalence of Anaemia - \% children under 5 years UNICEF

2. Economic status - GNI Per Capita, Atlas method (current US\$) - The World Bank

3. Gender status - Female Labour force participation, School enrolment of girls at secondary level (\%) - The World Bank

4. Status of public health system - Domestic government health expenditure (\% of current health expenditure), Domestic government health expenditure (\% of GDP), Domestic government health expenditure per capita (current US\$) - The World Bank

The study presents the descriptive and inferential analysis. Inferential analysis of ANOVA, Post Hoc test and Fixed Effects Panel Regression is done with the use of SPSS package.

\section{DATA ANALYSIS}

\section{A. DESCRIPTIVE ANALYSIS:}

Descriptive analysis gives the summary of year-wise prevalence of anaemia in the three selected countries.

Table 1 reveals that the extent of anaemia among children is highest in India followed by Bangladesh and Sri Lanka. It also shows that the annual rate of fall between years 2000 and 2017 is higher in Bangladesh and in Sri Lanka as compared to India.

\section{A. INFERENTIAL ANALYSIS:}

Research question 1: What is the comparative status of malnutrition among children among three selected countries in comparison with their selected economic and gender parameters? 
TABLE 1: PREVALENCE OF ANAEMIA AMONG CHILDREN IN THREE SELECTED COUNTRIES:

\begin{tabular}{|l|l|l|l|l|l|l|}
\hline YEAR & INDIA & $\begin{array}{l}\text { PER } \\
\text { ANNUM } \\
\text { CHANGE } \\
\text { (\% FALL) }\end{array}$ & BANGLADESH & $\begin{array}{l}\text { PER } \\
\text { ANNUM } \\
\text { CHANGE } \\
\text { (\% FALL) }\end{array}$ & SRI LANKA & $\begin{array}{l}\text { PER } \\
\text { ANNUM } \\
\text { CHANGE } \\
\text { (\% FALL) }\end{array}$ \\
\hline 2000 & 68.8 & & 62.2 & & 35.1 & \\
\hline 2001 & 67.9 & -1.31 & 60.9 & -2.09 & 34 & -3.13 \\
\hline 2003 & 67 & -1.33 & 59.6 & -2.13 & 33.2 & -2.35 \\
\hline 2004 & 66.1 & -1.34 & 58.2 & -2.35 & 32.4 & -2.41 \\
\hline 2005 & 65.4 & -1.06 & 56.8 & -2.41 & 31.6 & -2.47 \\
\hline 2006 & 64.5 & -1.38 & 55.5 & -2.29 & 30.9 & -2.22 \\
\hline 2007 & 63.6 & -1.40 & 54.1 & -2.52 & 30.2 & -2.27 \\
\hline 2008 & 62.7 & -1.42 & 52.7 & -2.59 & 29.2 & -3.31 \\
\hline 2009 & 61.8 & -1.44 & 51.2 & -2.85 & 28.4 & -2.74 \\
\hline 2010 & 61 & -1.29 & 49.6 & -3.13 & 27.5 & -3.17 \\
\hline 2011 & 60.4 & -0.98 & 48.1 & -3.02 & 26.8 & -2.55 \\
\hline 2012 & 59.7 & -1.16 & 46.5 & -3.33 & 26.1 & -2.61 \\
\hline 2013 & 59.1 & -1.01 & 44.9 & -3.44 & 25.5 & -2.30 \\
\hline 2014 & 58.5 & -1.02 & 43.5 & -3.12 & 25.3 & -0.78 \\
\hline 2015 & 58 & -0.85 & 42.3 & -2.76 & 25.2 & -0.40 \\
\hline 2016 & 57.6 & -0.69 & 41.2 & -2.60 & 25.3 & 0.40 \\
\hline 2017 & 57.3 & -0.52 & 40.3 & -2.18 & 25.6 & 1.19 \\
\hline & & & & & & \\
\hline
\end{tabular}

\section{TABLE 2: COMPARISON OF SELECTED COUNTRIES ON IMPORTANT PARAMETERS USING ANOVA}

\begin{tabular}{|c|c|c|c|c|c|}
\hline PARAMETER & COUNTRY & MEAN & $\begin{array}{l}\text { STD. } \\
\text { DEVIATION }\end{array}$ & $\begin{array}{l}\text { STD. } \\
\text { ERROR }\end{array}$ & SIG \\
\hline \multirow[t]{4}{*}{$\begin{array}{l}\text { Prevalence of Anaemia - \% } \\
\text { children under } 5 \text { years }\end{array}$} & Bangladesh & 50.43 & 7.41 & 1.74 & \multirow{4}{*}{0.00} \\
\hline & India & 62.03 & 3.85 & .90 & \\
\hline & Sri Lanka & 28.77 & 3.39 & .79 & \\
\hline & Total & 47.08 & 14.82 & 2.01 & \\
\hline \multirow[t]{4}{*}{ GNI per capita, (current US\$) } & Bangladesh & 796.11 & 340.81 & 80.33 & \multirow{4}{*}{0.00} \\
\hline & India & 1070.00 & 476.28 & 112.26 & \\
\hline & Sri Lanka & 2202.77 & 1189.64 & 280.40 & \\
\hline & Total & 1356.29 & 970.42 & 132.05 & \\
\hline
\end{tabular}




\begin{tabular}{|c|c|c|c|c|c|}
\hline $\begin{array}{l}\text { School enrolment of girls - } \\
\text { secondary level - \% }\end{array}$ & Bangladesh & 57.07 & 8.90 & 2.09 & \multirow{4}{*}{0.00} \\
\hline & India & 57.54 & 13.42 & 3.16 & \\
\hline & Sri Lanka & 98.56 & 1.84 & .43 & \\
\hline & Total & 71.06 & 21.67 & 2.94 & \\
\hline \multirow{4}{*}{$\begin{array}{l}\text { Domestic government health } \\
\text { expenditure (\% of current health } \\
\text { expenditure) }\end{array}$} & Bangladesh & 21.48 & 3.10 & .73 & \multirow{4}{*}{0.00} \\
\hline & India & 22.97 & 3.63 & .85 & \\
\hline & Sri Lanka & 47.15 & 5.16 & 1.21 & \\
\hline & Total & 30.53 & 12.52 & 1.70 & \\
\hline \multirow{4}{*}{$\begin{array}{l}\text { Domestic government health } \\
\text { expenditure (\% of GDP) }\end{array}$} & Bangladesh & .49 & .056 & .01 & \multirow[t]{4}{*}{0.00} \\
\hline & India & .83 & .08 & .01 & \\
\hline & Sri Lanka & 1.85 & .27 & .06 & \\
\hline & Total & 1.06 & .60 & .08 & \\
\hline \multirow{4}{*}{$\begin{array}{l}\text { Domestic government health } \\
\text { expenditure per capita (current } \\
\text { US\$) }\end{array}$} & Bangladesh & 3.78 & 1.38 & .32 & \multirow[t]{3}{*}{0.00} \\
\hline & India & 9.66 & 4.97 & 1.17 & \\
\hline & Sri Lanka & 42.64 & 16.78 & 3.95 & \\
\hline & Total & 18.69 & 19.92 & 2.71 & \multirow[t]{5}{*}{0.00} \\
\hline \multirow[t]{4}{*}{$\begin{array}{l}\text { Female Labour force } \\
\text { participation (\%) }\end{array}$} & Bangladesh & 29.68 & 2.44 & 0.57 & \\
\hline & India & 26.80 & 4.09 & 0.96 & \\
\hline & Sri Lanka & 35.96 & 1.25 & 0.29 & \\
\hline & Total & 30.82 & 4.76 & 0.64 & \\
\hline
\end{tabular}

*. The mean difference is significant at the 0.05 level.

The above table reveals following things:

- $\quad$ The prevalence of anaemia among children up to 5 years is lowest in Sri Lanka followed by Bangladesh. It is highest (62 \%) in India. The difference across the three countries is statistically significant as $P<0.5$.

- The difference in other socio-economic parameters is also found out to be statistically significant $(P<0.5)$. It can be seen that Sri Lanka has lowest prevalence of malnutrition among children. On all the other economic and gender parameters it has significantly higher mean as compared with India and Bangladesh.

- It must be noted that Bangladesh has significantly lower prevalence of malnutrition among children than India irrespective of having lower per capita income and lower per capita public health expenditure. It is also observed that the percentage of females labour force participation is significantly higher in Bangladesh as compared to India. 
TABLE 2: POST HOC TEST OF COMPARISON OF THREE SELECTED COUNTRIES ON PREVALENCE OF MALNUTRITION:

\begin{tabular}{|l|l|l|l|l|}
\hline $\begin{array}{l}\text { (I) COUNTRY } \\
\text { CODE }\end{array}$ & $\begin{array}{l}\text { (J) COUNTRY } \\
\text { CODE }\end{array}$ & $\begin{array}{l}\text { MEAN } \\
\text { DIFFERENCE (I-J) }\end{array}$ & STD. ERROR & SIG. \\
\hline Bangladesh & India & $-11.60^{*}$ & 1.73 & .000 \\
\hline & Sri Lanka & $21.66^{*}$ & 1.73 & .000 \\
\hline India & Bangladesh & $11.60^{*}$ & 1.73 & .000 \\
\hline & Sri Lanka & $33.26^{*}$ & 1.73 & .000 \\
\hline Sri Lanka & Bangladesh & $-21.66^{*}$ & 1.73 & .000 \\
\hline & India & $-33.26^{*}$ & 1.73 & .000 \\
\hline
\end{tabular}

*. The mean difference is significant at the 0.05 level.

The post Hoc test shows that the extent of malnutrition between three countries is also statisticallysignificant.

It can be concluded that India has significant high prevalence of malnutrition among children in comparison with Bangladesh and Sri Lanka.
Research question 2: What is the impact of economic and gender factors such as GNI per capita, gender status, and public healthcare expenditure on the extent of malnutrition among children?

The study has used Fixed Effects Panel Regression Model to analyse the panel data of longitudinal observations of three countries over the period of 17 years. The output of the model is given below:

TABLE 3: FIXED EFFECTS PANEL REGRESSION ANALYSIS:

\begin{tabular}{|c|c|c|c|c|c|}
\hline FACTORS & $\begin{array}{l}\text { UNSTANDARD } \\
\text { IZED } \\
\text { COEFFICIENTS }\end{array}$ & $\begin{array}{l}\text { STANDARDIZED } \\
\text { COEFFICIENTS }\end{array}$ & $\begin{array}{l}\text { UNSTANDARD } \\
\text { IZED } \\
\text { COEFFICIENTS }\end{array}$ & $\mathbf{T}$ & SIG \\
\hline (Constant) & 95.309 & 7.839 & & 12.158 & .000 \\
\hline Dummy Variable Sri Lanka & -1.816 & 6.528 & -.058 & -.278 & .782 \\
\hline Dummy Variable India & 16.866 & 2.702 & .541 & 6.243 & .000 \\
\hline GNI per capita & -.007 & .002 & -.478 & -3.093 & .003 \\
\hline $\begin{array}{l}\text { School enrolment girls - } \\
\text { secondary level - \% }\end{array}$ & -.337 & .056 & -.492 & -5.988 & .000 \\
\hline $\begin{array}{l}\text { Female Labour force parti. } \\
(\%)\end{array}$ & -.413 & .158 & -.133 & -2.610 & .012 \\
\hline $\begin{array}{l}\text { Domestic govt. health } \\
\text { expen. PC }\end{array}$ & .308 & .150 & .413 & 2.051 & .046 \\
\hline $\begin{array}{l}\text { Domestic govt. health } \\
\text { expen. (\% of current health } \\
\text { expen.) }\end{array}$ & .093 & .128 & .078 & .725 & .472 \\
\hline $\begin{array}{l}\text { Current health expen. (\% of } \\
\text { GDP) }\end{array}$ & -4.617 & 1.745 & -.233 & -2.645 & .011 \\
\hline
\end{tabular}

a. Dependent Variable: Prevalence of Anaemia - \% children under 5 


\begin{tabular}{|c|c|c|c|c|}
\hline MODEL & $\mathbf{R}$ & R SQUARE & ADJUSTED R SQUARE & $\begin{array}{c}\text { STD. ERROR OF THE } \\
\text { ESTIMATE }\end{array}$ \\
\hline 1 & $.992^{a}$ & .983 & .980 & 2.09089 \\
\hline
\end{tabular}

\section{FINDINGS FROM REGRESSION ANALYSIS}

Prevalence of anaemia among children up to 5 years $=$ $95.30-0.007 \mathrm{PCl}-0.337$ School enrolment of girls - secondary level - \% - 0.413 Labour force participation of female (\%) + 0.308 Domestic government health expenditure - 4.61 Domestic government health expenditure (\% of GDP)

The regression analysis shows that:

1. Out of the six selected independent factors GNI Per Capita, School enrolment of girls at the secondarylevel (\%), Female labour force participation (\%), Domestic government health expenditure (\% of GDP), and Domestic government health expenditure Per Capita and Domestic Government's Health Expenditure (\% of GDP) (\% of current health expenditure) are found to have statistically significant impact on prevalence of malnutrition among children.

2. One independent variables of Domestic government health expenditure as percentage of current health expenditure does not show statistically significant impact.

3. The analysis proves that gender status measured in terms of access to secondary level of education to girls and their labour force participation has statistically negative impact on prevalence of malnutrition among children. This result is justified in the theory.

4. It is observed that domestic government health expenditure as percentage of GDP is showing a positive impact with prevalence of malnutrition among children. Theoretically it cannot be justified. At the same time this finding might have come due to the fact that though India spends significantly higher proportion of GDP on health as compared to Bangladesh, Bangladesh has better results in reducing the prevalence of malnutrition.

\section{CONCLUSIONS}

Following conclusions can be drawn from the data analysis:

- Prevalence of malnutrition among three countries is significantly different with Sri Lanka having the lowest proportion followed by Bangladesh.

- The regression analysis shows that prevalence of malnutrition among children is affected by gender status measured in terms of school enrolment of girls at secondary level and female labour force participation as well as by $\mathrm{PCl}$ and the proportion of government expenditure in total health expenditure.

- It can be concluded that role of public health expenditure is veryimportant in reducing the burden of out-of-pocket expenses on health and providing an easy and affordable access of healthcare which goes a long way in reducing the extent of malnutrition among children.

- It can also be concluded that gender development policies which empower women through education and their active role in the economic activities also play a significant role in taking better care of themselves and their children which will go long way to reduce malnutrition among children.

- The example of Bangladesh shows, special nutrition programmes focussing on children below 5 years and bringing out behavioural changes in pregnant women and young mothers in improving child feeding practices are important for reducing the prevalence of malnutrition among children. Bangladesh achieved this by integrating gender empowerment policies with health policies.

\section{RECOMMENDATIONS:}

The study recommends that integration of public healthcare policies and gender empowerment policies will be useful for reducing the extent of malnutrition among children. 


\section{References:}

1. Müller O, Krawinkel M. Malnutrition and health in developing countries. CMAJ. 2005 Aug; 173(3), 279286. https://doi.org/10.1503/cmaj.050342.

2. Bain LE, Awah PK, Geraldine N, Kindong PN, Sigal Y, Bernard $\mathrm{N}$ et al. Malnutrition in Sub - Saharan Africa: burden, causes and prospects, Pan Afr Med J. 2013, Aug; 6;15:120.. doi: 10.1 1604/pamj.2013.15.120.2535.

3. Akseer N, Kandru G, Keats EC, Bhutta ZA. COVID-19 pandemic and mitigation strategies: implications for maternal and child health and nutrition. The American Journal of Clinical Nutrition, 2020 Aug; Vol 1 12, Issue2, 251-256, https://doi.org/10.1093/ajcn/nada171

4. Mishra VK, Retherford RD. Women's Education Can Improve Child Nutrition in India, Natl Fam Health Surv bull, 2000 Feb; (15):1-4.

5. Hasan MT, Magalhaers RJ, Williams GM, Mamun AA. The role of maternal education in the 15-year trajectory of malnutrition in children under 5 years of age in Bangladesh, Matern Child Nutr. 2016 Oct; 12:929-39. doi: 10.1111/mcn.12178. Epub 2015 Feb 26.

6. Wie GT, Tsegaye D. Determinants of Acute Malnutrition among Children Aged 6-59 Months Visiting Public Health Facilities in Gambella Town, Southwest Ethiopia: Unmatched Case-Control Study. 202 July; Nutrition and Dietary Supplements, 12, 147-156. doi:http://dx.doi.org/10.2147/NDS.S256000.

7. Ahmed S, Creanga AA, Gillespie DG, Tsui AO. Economic Status, Education and Empowerment: Implications for Maternal Health Service Utilization in Developing Countries, 2010; PLOS ONE 5(6): e 11190. https://doi.org/10.1371/journal.pone.0011190

8. Suri S. Breakout Nation: The Nutrition Transformation of Bangladesh, ORF Issue Brief, 2019 Nov; Issue 323.

9. Singh, S., Srivastava, S. \& Upadhyay, A.K. Socioeconomic inequality in malnutrition among children in India: an analysis of 640 districts from National Family Health Survey (2015-16). International Journal for Equity in Health 18, 203, 2019. https://doi.org/10.1186/s12939-019-1093-0

10. Boachie MK, Ramu K., Põlajeva T. Public Health Expenditures and Health Outcomes: New Evidence from Ghana. Economies, 2018 Oct; 6(4), 1-25. doi:http://dx.doi.org/10.3390/economies6040058
11. Makela SM., Dandona R, Dilip T R, Dandona L. Social Sector Expenditure and Child Mortality in India: A State-Level Analysis from 1997 to 2009. PLoS One, 8(2), 2013 Feb; 1-10, doi:http://dx.doi.org/10.1371/journal.pone.0056285.

12. The Bangladesh Integrated Nutrition Project: effectiveness and lessons (English). Bangladesh Development Series; paper no. 8 Washington, D.C. : World Bank Group.

http://documents.worldbank.org/curated/en/5926414 68013784606/The-Bangladesh-Integrated-NutritionProject-effectiveness-and-lessons

13. Zaidi AK, Awasthi S, deSilva HJ. Burden of infectious diseases in South Asia, BMJ, 2004 Apr; 328 (7443): 811 5. doi: $10.1136 / \mathrm{bmj} .328 .7443 .811$.

14. Mundle S. Millennium Development Goals: How is India Doing?, Working Papers 1 1/93, 2011 ; National Institute of Public Finance and Policy. 1-14.

15. Rajpal S, Joe W, Subramanyam MA, Sankar R, Sharma S, Kumar A et al. Utilization of Integrated Child Development Services in India: Programmatic Insights from National Family Health Survey, IJERPH, 2020 May; 17(9), 3197. doi:http://dx.doi.org/10.3390/ijerph17093197. 